\title{
非晶質ナノシリカの動態特性と生殖発生毒性
}

\author{
長 野一也

\section{Biodistribution of Nanosilica Particles in Pregnant Mice and the Potential Risk on the Reproductive Development}

\author{
Kazuya NAGANO \\ Laboratory of Biopharmaceutical Research, National Institute of Biomedical Innovation, \\ 7-6-8 Saito-Asagi, Ibaraki, Osaka 567-0085, Japan
}

(Received September 3, 2010)

\begin{abstract}
Nanomaterials acquire revolutionary functions such as anti-inflammatory and anti-viral effects by increasing surface area per unit weight, due to the reduction to nano size. Such nanomaterials are rapidly put to practical use without safety evaluation. This is because it is widely assumed that nanomaterials are merely of the same molecular composition as existing materials of more than submicron size, and that nanomaterials cannot be absorbed from the digestive tract or skin as is the case with existing materials of more than submicron size. On the other hand, as was the case with thalidomide, evidence shows that fetuses and infants are affected more than adults by a variety of environmental toxins, because of physiological immaturity. Thus, placental or breast milk-mediated exposure to nanomaterials may possibly induce unexpected biological effects. To our knowledge, however, no studies have examined effects of pregnant animal exposure to nanomaterials on transitivity to placenta or infants, or on maintenance of pregnancy. Therefore, using nanosilica particles (nSPs) employed as additives in cosmetics and foods, we will report on the efficiency of transitivity of nSPs of various diameters to the circulation through the placental barrier after nanomaterial exposure and the risks of nSP exposure to pregnant mice. In this review, I will discuss the development of safety in nanomaterials and the maintenance of good health.
\end{abstract}

Key words_ nanosilica particle; placental barrier; safety in nanomaterial

\section{1. はじめに}

近年のナノテクノロジーの進展も相まって，ナノ 酸化チタンやフラーレン, 非晶質シリカを始めとす る様々なナノマテリアルが開発され，医薬品や化粧 品, 食品といつた人体に直接適用する分野での実用 化が進んでいる.1,2) これらは，ナノサイズであるが ゆえの物性に基づき，組織浸透性・抗炎症作用など の点で, 従来までのマイクロサイズ素材とは異なつ た画期的機能を発揮することから，種々の産業にパ ラダイムシフトを起こすものと期待されている.こ のような背景の下, ナノマテリアル産業の世界市場 は，今後も拡大の一途を辿ると予想されている. その一方で，これらナノマテリアルの実用化は，

独立行政法人医薬基盤研究所バイオ創薬プロジェクト （干567-0085 大阪府茨木市彩都あさぎ 7-6-8）

e-mail: knagano@nibio.go.jp

本総説は, 日本薬学会 130 年会シンポジウム S18 で発 表したものを中心に記述したものである.
(1)ナノマテリアルが従来までのサブミクロンサイズ 以上の粒子と分子組成的に同じであること，(2)また これら従来型粒子は消化管，鼻粘膜，皮膚からほと んど吸収されないため, ナノマテリアルも同様に吸 収されるはずがないということを前提として，十分 な安全性が評価されないまま, 加速度的に進展して いる. その点, 筆者らの研究グループではこれまで に，ナノスケールにまでサイズダウンされた非晶質 ナノシリカが従来型シリカとは異なり，皮膚や消化 管を介して吸収され，体内に分布し，生体に影響を 与える可能性を見い出している (角田の稿を参照). これらの結果は, 非晶質ナノシリカに曝露されるこ とで，体内へと侵入した非晶質ナノシリカが，生殖 器官・胎児へ移行した場合，催奇形性を始めとする 生殖発生毒性を発現する可能性をも示している。特 に胎児や乳幼児は，血液脳関門や免疫系といつた生 体防御機構が未発達であるため，成人では影響がみ られない曝露量であっても大きな影響が及ぶ可能性 
がある。したがって，サリドマイドの副作用によっ て，多くの新生児が奇形をもって生まれてきた悲劇 を繰り返さないためにも, ${ }^{3,4)}$ 次世代影響を見据えた 胎児に対する安全性，及び新生览の成長過程におけ る影響を精查することは必要不可欠である。しか し，ナノマテリアルの生殖発生に与える影響評価は 世界的にも始まったばかりである。本観点から，ナ ノマテリアルの適切なリスク管理を実現し，有用な ナノマテリアルを安全に，安心して使用するために は，ナノマテリアルの生殖組織への移行性や影響を 詳細に追求する必要が考えられる.

そこで筆者らは，ナノマテリアルの生殖発生に与 える影響の評価を目的に，既に食品添加物などとし て利用され，その使用量が多い非晶質ナノシリカを モデルに, ${ }^{5-7)}$ シリカの粒子径の違いによる, 組織 分布，生殖発生に与える影響の三者連関解析を進め ている（Fig. 1)。本稿では，それらの取り組みつ いて紹介させて頂きたい.

\section{2. 非晶質ナノシリカの組織分布解析}

上述のように筆者らのグループはこれまでに，従 来型のサブミクロンサイズである直径 $300 \mathrm{~nm}$, $1000 \mathrm{~nm}$ の非晶質シリカは皮膚に塗布しても吸収さ れなかったのに対して，直径 $70 \mathrm{~nm}$ の非晶質ナノ シリカは角質層を通過し，表皮層にまで到達すると ともに，全身血流に移行し得ることを明らかとして いる（角田の稿を参照）。そこで，筆者らは，妊娠 マウスを用いて，非晶質ナノシリカの血中移行後の 組織分布を解析した。蛍光修飾された粒子径 1000 $\mathrm{nm}, 300 \mathrm{~nm}, 70 \mathrm{~nm}$ の各非晶質シリカ（以後それぞ れ， mSP1000, nSP300, nSP70 と表記）を，胎盤が 形成されて安定期に入った妊娠 16 日目のマウスに 尾静脈内投与し，in vivo imagingにより各粒子の 挙動を観察した。その結果，いずれの粒子を投与し た場合でも，肝臓で強い蛍光が観察され，大部分は 血中から肝臓へ速やかに集積することが明らかとな つた。しかし，nSP70 投与群においてのみ，コン トロール群と比較して胎盤でも蛍光が観察された。 したがって，投与された nSP70 の一部は胎盤に移 行し得ることが示された。

続いて，より詳細に組織分布を解析するため, 透 過型電子顕微鏡（TEM）を用いて各非晶質シリカ を直接観察し，その局在を評価した。 各粒子径の非 晶質ナノシリカを妊娠後期マウスに尾静脈内投与 し, 出生直前に帝王切開により胎盤と胎仔を回収後, TEMにより観察した. その結果, nSP300 や mSP1000 の従来型シリカ投与群では, これら組織に粒子の存 在は認められなかったのに対して, nSP70 投与群 では，胎盤の栄養膜層や迷宮層部分において粒子の 存在が確認された。胎盤は, 胎仔の発育に重要な役 割を担う組織であるため, nSP70 が胎盤へと移行 することにより，胎仔へ影響が及ぶ可能性が示され た.

そこで次に，非晶質ナノシリカが胎盤を通過し， 胎仔へも移行し得る可能性を考慮し, 胎仔の各組織 を回収して TEMにより観察した。その結果， $\mathrm{nSP} 300$ や mSP1000 の従来型シリカ投与群では,

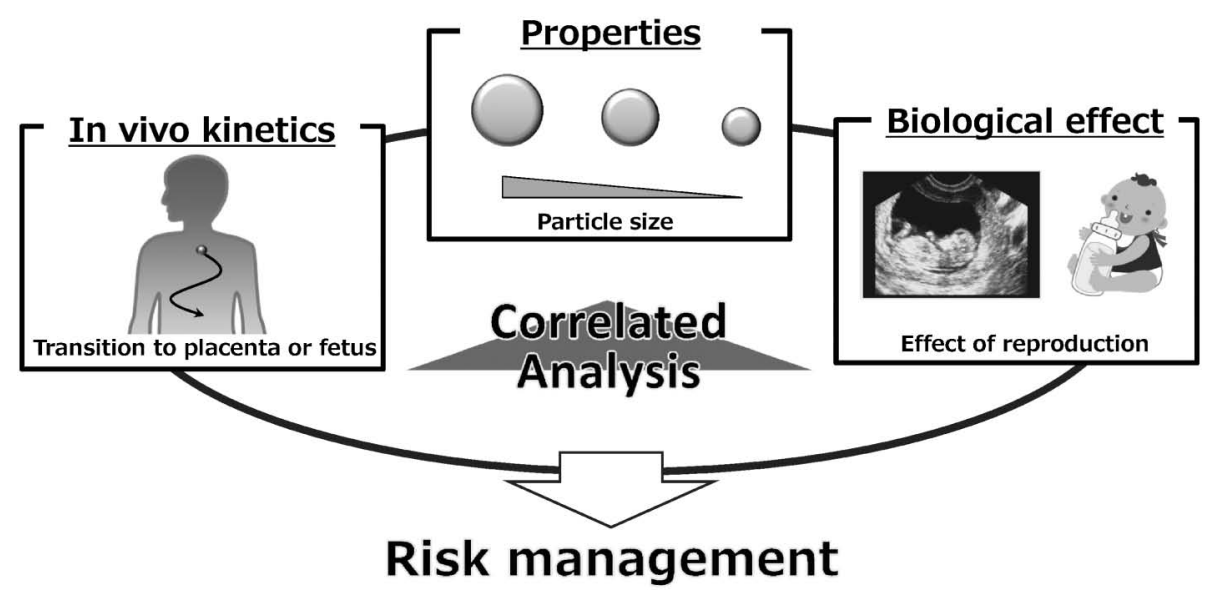

Fig. 1. Strategy for Risk Management of Nanomaterials

We aim for risk management of nanomaterials by analyzing relationship among property, in vivo kinetics and biological effect. Here we introduce about transition to placenta or fetus and effect of reproduction from differing particle size. 
胎仔への移行が観察されなかった一方で，nSP70 投与群では，胎仔の肝臟，さらには脳においても粒 子が観察された。このことより，妊娠時に体内に入 った nSP70 は，血液一胎盤関門を通過し，胎仔にま で移行し得ることが明らかとなった。今後は，血中 から胎盤・胎仔に移行する nSP70 を定量的に解析 するとともに，蓄積性などを詳細に検討していくこ とが重要と考えられる。

\section{3. 非晶質ナノシリカの生体影響評価}

次に筆者らは, 非晶質ナノシリカの組織分布の結 果を踏まえ，生体影響について解析した。まず，母 体への影響評価の一環として，各粒子径の非晶質シ リカを投与したマウスの血液を回収し，赤血球・白 血球・血小板・顆粒球数を比較した。 その結果，い ずれの項目もコントロール群と比較して有意な差は 認められず，母体の血球成分には影響を与えないこ とが示唆された。

続いて，胎仔の発育に与える影響を評価した。各 粒子径の非晶質シリカを投与した妊娠マウスから帝 王切開により胎仔と胎盤を取り出し, 胎仔数・胎仔 重量・胎盤重量をそれぞれ比較した。その結果，胎 仔数・胎盤重量に関しては，いずれの群においても コントロール群と比較して有意な差は認められなか った。一方で，胎仔重量に関しては，nSP70 投与 群でのみ有意に低下していた。この結果は，なんら かの原因で子宮内での胎児の発育が抑制又は停止
し，正常範囲を逸脱して発育が遅れる「子宮内胎児 発育遅延 (intrauterine growth retardation: IUGR) $\lrcorner^{8,9)}$ 様の症状を引き起こしている可能性も示された。わ が国でも低体重児の出産が増加しており，今後，非 晶質ナノシリカと IUGR との関連を慎重に解析し ていく必要が考えられる.

最後に，次世代に及ぼす影響を評価すべく， nSP70 が投与されたマウスから出生したマウス（6 週齢）の血球成分を測定した。その結果，コント ロール群と比較して，赤血球数，血小板量には差が 認められなかったのに対して，白血球数や顆粒球数 は nSP70 投与群で顕著に増加していた。 以上の結 果は，母体に非晶質ナノシリカが曝露されることで, IUGR 様の症状が誘発される可能性に加え, 出生後 の免疫機能にも影響を及ぼし，アレルギー性疾患な どの発症に関与する可能性も考慮する必要があるこ とを示している（Fig. 2)。さらに近年，低体重児 のメタボリックシンドロームとの関連が報告されて いることから，今後は，アレルギ一疾患に加え，糖 尿病や肥満といつた疾患との関連についても調査し ていく予定である.

\section{4. 結論と展望}

薬学研究においては, 有効な医薬品開発を目指す ことに加え，医薬品や食品，化粧品などに含有され る物質によって健康被害が引き起こさないように, 適正な使用と安全性の確保に寄与することも大切な

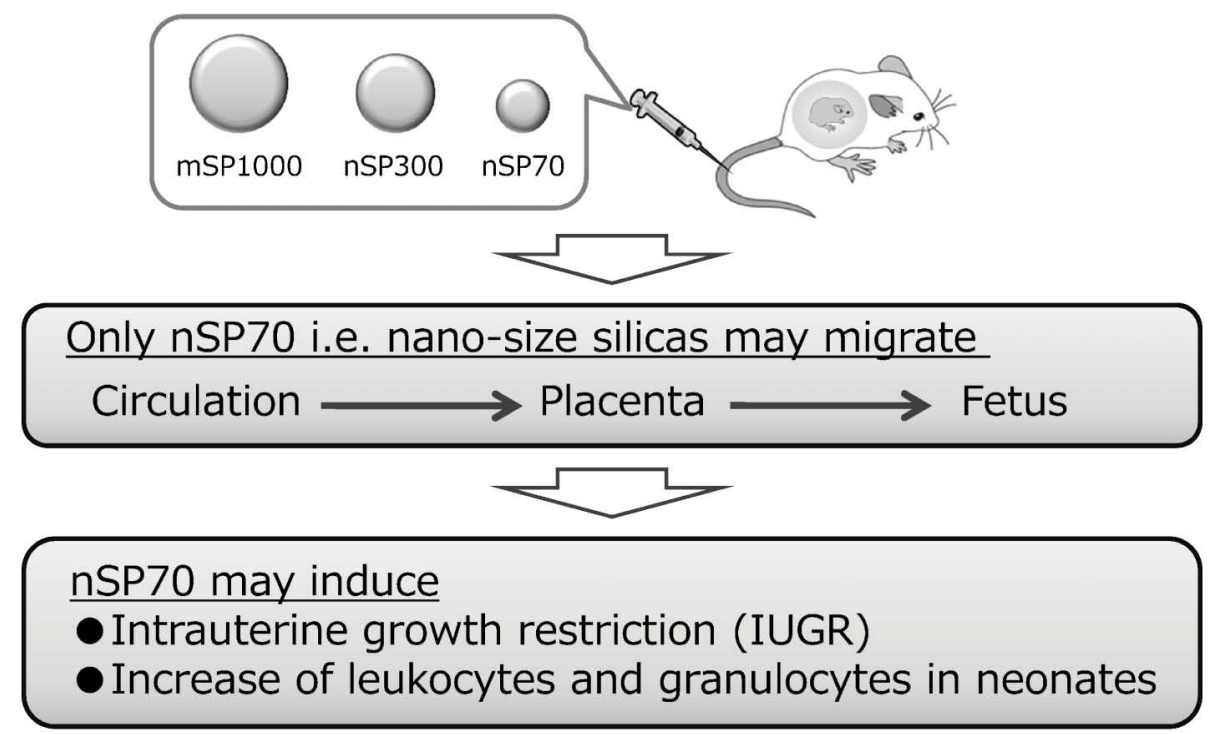

Fig. 2. Summary of the Correlated Analysis

Only nSP70 nano-size particles may migrate from circulation to placenta and fetus. They may induce the intrauterine growth restriction and the increase of leukocytes and granulocytes in neonates. 
使命の 1 つである. 本観点から筆者らは, 近年, 安 全性が危惧され始めたナノマテリアルに対し て, ${ }^{10,11)}$ 安全なナノマテリアルの開発支援と科学的 根拠に基づいた利用指針の作成を目標に，非晶質ナ ノシリカの物性-生体内動態-生殖発生に与える影響 評価の三者連関情報の集積を試みた。本検討によ り，サブミクロンサイズ以上の従来型のシリカは血 中に移行した場合でも，生殖発生への影響は認めら れなかった。一方で，粒子径 $100 \mathrm{~nm}$ 以下のシリカ が，妊婦の血中に移行した場合には，胎盤へと移行 し, 胎児の発育に影響を与える可能性が示された。 したがって，非晶質ナノシリカを安全に，かつ安心 して使用していくためにも，血中から胎盤へ，胎盤 から胎仔への移行量を定量するとともに，生殖発生 毒性に対する無作用量や無影響量を決定する必要が ある，さらに，実際に，非晶質ナノシリカが曝露さ れる経皮や経口投与による安全性評価も早急に進め られなければならない。

その一方で本研究において最も重要なことは, 単 に危険性を㮼るのではなく, 科学的に集積された情 報からいかにナノマテリアルを安全に使用するか, 又はいかに安全なナノマテリアルを開発するかにあ る，その点，筆者らのグループでは，これまでの検 討から，同じ粒子径であっても表面電荷を変化させ ることで，急性毒性を軽減可能であることを見い出 している，そのため，現在これらの非晶質ナノシリ 力を用いて，生殖発生に与える影響評価を進めてい る。 今後は, より詳細に物性一生体内動態-生殖発生 に与える影響評価の三者連関を解析することで，例 えば「この物性のナノマテリアルは，この量であれ ばこういつた動態を示すため安全である」といつ た，「安全にナノマテリアルを使用するための指針 策定」や「安全なナノマテリアルの開発」に有用な 情報を提供することが可能となり，科学的根拠に基 づいたリスク管理やナノマテリアルの社会受容の促 進に貢献できるものと期待している.

謝辞本研究は, 独立行政法人医薬基盤研究所 バイオ創薬プロジェクト・サブリーダー鎌田春彦先
生を始めとする多くの先生方のご指導の下, 山下浩 平氏，吉田徳幸氏，東阪和馬氏，藤村真穂氏，中西 亮介氏，森下裕貴氏など，独立行政法人医薬基盤研 究所バイオ創薬プロジェクトの皆さまとの共同成果 であり，この場をお借りして，御礼を申し上げま す。また種々ご指導，ご助言を賜りました神戸学院 大学薬学研究科教授眞弓忠範先生, 同研究科教授河 合裕一先生, 富山大学付属病院産婦人科教授斉藤 滋先生, 大阪府母子センター柳原 格先生, 藤田保 健衛生大学宮川 剛先生, 独立行政法人医薬基盤研 究所共同機器室室長今澤孝喜先生に感謝の意を表し ます。

\section{REFERENCES}

1) Kayser O., Lemke A., Hernandez-Trejo N., Curr. Pharm. Biotechnol., 6, 3-5 (2005).

2) Meghea A., Recent Pat. Nanotechnol., 2, 137145 (2008).

3) Stephens T. D., Bunde C. J., Fillmore B. J., Biochem. Pharmacol., 59, 1489-1499 (2000).

4) Therapontos C., Erskine L., Gardner E. R., Figg W. D., Vargesson N., Proc. Natl. Acad. Sci. USA, 106, 8573-8578 (2009).

5) Barik T. K., Sahu B., Swain V., Parasitol. Res., 103, 253-258 (2008).

6) Rahman A., Seth D., Mukhopadhyaya S. K., Brahmachary R. L., Ulrichs C., Goswami A., Naturwissenschaften, 96, 31-38 (2009) .

7) Villota R., Hawkes J. G., Crit. Rev. Food Sci. Nutr., 23, 289-321 (1986).

8) Cetin I., Alvino G., Placenta, 30 (Suppl. A), S77-S82 (2009).

9) Scifres C. M., Nelson D. M., J. Physiol., 587, 3453-3458 (2009).

10) Poland C. A., Duffin R., Kinloch I., Maynard A., Wallace W. A., Seaton A., Stone V., Brown S., Macnee W., Donaldson K., Nat. Nanotechnol., 3, 423-428 (2008).

11) Takagi A., Hirose A., Nishimura T., Fukumori N., Ogata A., Ohashi N., Kitajima S., Kanno J., J. Toxicol. Sci., 33, 105-116 (2008). 